\title{
Prodrugs: Overcoming Drugs' Obstacles by Inactive Precursors
}

\author{
Souza, M. C. B. A.; Huchting, J.*
}

Rev. Virtual Quim., 2016, 8 (5), 1485-1509. Data de publicação na Web: 6 de agosto de 2016

http://rvq.sbq.org.br

\section{Pró-Fármacos: Superando Obstáculos de Fármacos com Precursores Inativos}

Resumo: De que forma um agente ativo pode ser modificado quimicamente para que a druglikeness (índice de semelhança a fármacos) - descrita pelos parâmetros $A D M E(T)$-aumente e, assim, após a ativação química ou enzimática, o composto original seja liberado para exercer o seu efeito farmacológico? Como alterações bioreversíveis à estrutura de um agente ativo pode aumentar a site-specificity (especificidade de local) e, desta forma, permitir uma maior eficácia e efeitos secundários reduzidos? Este artigo tem como objetivo descrever, com exemplos, alguns dos conceitos básicos disponíveis para atender a determinados aspectos da drug-likeness de um agente ativo fazendo uso da estratégia de pró-fármaco. Não se pretende, no entanto, exaurir o tema em qualquer aspecto e sim transmitir os princípios fundamentais da escolha de estratégias de pró-fármaco para fornecer ao leitor uma primeira ideia a respeito desses conceitos, apresentando-o a alguns exemplos.

Palavras-chave: Pró-fármaco; pré-fármaco; porções inativas; parâmetros ADME(T).

\begin{abstract}
How can an active agent be chemically modified, so that the drug-likeness - described by the $\operatorname{ADME}(\mathrm{T})$-parameters - increases and then, upon chemical or enzymatic activation, it sets free the parent compound to exert its pharmacological effect? How can bioreversible changes to the structure of an active agent enhance site-specificity and thereby allow for higher efficiency and lowered side-effects? This article aims at describing some of the basic concepts that are available to address certain aspects of the drug-likeness of an active agent by making use of a prodrug strategy. It does not, however, claim completeness in any aspect. In fact, it is thought to convey the fundamental principles of select prodrug-strategies to give the reader a first idea of these concepts while being introduced to some examples.
\end{abstract}

Keywords: Prodrug; predrug; bioprecursor; promoieties; ADME(T)-parameters.

\footnotetext{
* Universidade de Hamburgo, Faculdade de Matemática, Informática e Ciências Naturais, Departamento de Química, Instituto de Química Orgânica, Martin-Luther-King-Platz 6 20146, Hamburgo, Alemanha.

Mhuchting@chemie.uni-hamburg.de

DOI: $\underline{10.21577 / 1984-6835.20160105}$
} 


\title{
Prodrugs: Overcoming Drugs' Obstacles by Inactive Precursors
}

\author{
Maria Claudia B. A. Souza, ${ }^{a}$ Johanna Huchting ${ }^{\mathrm{b}, *}$
}

a Universidade Federal Fluminense, Instituto de Química, Departamento de Química Orgânica, Campus do Valonguinho, CEP 24020-150, Niterói-RJ, Brasil.

${ }^{\mathrm{b}}$ Universidade de Hamburgo, Faculdade de Matemática, Informática e Ciências Naturais, Departamento de Química, Instituto de Química Orgânica, Martin-Luther-King-Platz 6 20146, Hamburgo, Alemanha.

*huchting@chemie.uni-hamburg.de

Recebido em 15 de janeiro de 2016. Aceito para publicação em 1 de agosto de 2016

\section{Introduction}

2. First prodrugs - A concept that was made use of before its conceptual existence

3. Increasing water solubility

4. Enabling the passage through cell-membranes ( $\&$ impeding back-diffusion)

4.1. Enhancing the absorption from the GIT

4.2. Allowing for simple diffusion into target cells/tissues

4.3. Permitting active uptake from systemic circulation

5. Lowering Toxicity and adverse-effects - Prodrugs for site-specific activation and targeted drug-delivery

6. Increasing metabolic stability \& enhancing a drugs half-life

7. The impact of the prodrug strategy on current treatments $\&$ what the future holds

\section{Concluding remarks}

\section{Introduction}

There are numerous requirements an active agent has to meet to become an actual drug. Albeit fundamental, the interference with a molecular target of biological importance itself is only one of many crucial qualifying factors. Its pharmacokinetic properties, described by the $\operatorname{ADME}(T)$ parameters - absorption, distribution, metabolism, excretion, (toxicity) - hugely influence the potency of an active agent: It has to reach its target to initiate a certain pharmacological effect. Therefore, to be orally bioavailable, it has to be absorbed from the gastrointestinal tract (GIT). This requires a good balance between water solubility and lipophilicity of the drug (partition coefficient), if not actively transported. For parenteral administration as well, solubility must be considered. 
Once absorbed to the blood stream, the drug has to reach its target tissue and therein the molecular target that may lie inside the cell. If not bound to plasma proteins or absorbed by fatty tissues, the distribution of a drug around the blood supply is quite quick, although for orally/rectally administered drugs, first pass effects must be payed attention to. Distribution problems then can occur at the cell membrane: to pass this barrier a drug has to either be sufficiently lipophilic or to be actively transported. The blood-brain-barrier especially restricts compounds with high molecular weights and high polar surface areas and those exhibiting low lipophilicity from reaching areas of the central nervous system.

A further limitation to the efficacy of a drug lies in its metabolism: The organisms' metabolizing enzymes aim at modifying foreign molecules to render them more prone to excretion. The metabolites of a drug can simply be inactive and quickly excreted, but they can also possess activity themselves, which may be different from that of the parent compound. This, on one hand, can account for side effects or toxicity, but, on the other hand, can also be profited from. Typical metabolizing reactions are oxidations, reductions, ester/amide hydrolysis (phase I) and conjugation reactions (phase II).

These parameters that have a crucial impact on the efficacy of a drug directly result from its chemical structure. Therefore, changing the structure might enhance the efficacy. But changing a drug's structure also has a strong influence on its pharmacodynamics - it might turn an active agent into a less-active or non-active compound.

One strategy to influence pharmacokinetic parameters of an active agent for the better, without changing the activity profile at the site of action, is the prodrug approach.

The term "pro-drug" was first mentioned by Albert in his 1958 Nature paper on "chemical aspects of selective toxicity". In this article, Albert defines a "pro-drug" as a substance "which has to be broken down to give the true drug". ${ }^{1}$ The term 'break down' allows for a wide range of metabolic processes to go from "pro-drug" to "true drug" as well as non-enzymatic, chemical activating reactions which themselves can again be initiated by divers triggers (e.g $\mathrm{pH}$, light). Despite this quite expansive definition Albert claims a substance being "only a prodrug" to be "a rare phenomenon". Looking at the latest numbers, this certainly can be refuted from today's point of view. ${ }^{2}$

One year later, Harper described the concept of "drug latentiation", which he defines as "the chemical modification of a biologically active compound to form a new compound, which upon in vivo enzymatic attack will liberate the parent compound." This can be understood to describe the same strategy as the "pro-drug" concept mentioned before. The rationale behind this, as written by Harper, is the "attachment of a carrier group to the active drug to alter its physicochemical properties" - especially the $A, D$ and $M$ of the $\operatorname{ADME}(T)$, as can be drawn from his paper - "and then the subsequent enzymic attack to liberate the active drug moiety". ${ }^{3}$ Harper thus confines his concept to the enzymatic activation of the latentiated drug and he emphasizes the important fact that "the nature of the carrier group $X$ will obviously influence not only the absorption and distribution of the inactive transport form but also the rate of release of the active drug moiety". Using the wider definition of a "pro-drug" by Albert (to which this article will stick, as it has been generally accepted), it can undoubtedly be stated that the same correlations hold true for non-enzymatically cleaved promoieties.

Different approaches have been developed for addressing the many drawbacks an ex vivo active compound can possess in vivo that meet the prodrugrequirements: Modifying the drug's structure to overcome its pharmacokinetic disadvantages in a way that the active compound will be "set free" at its site of action so that it can exert its potential for therapy. Many think of a prodrug being a drug-promoiety conjugate either with the 
promoiety itself producing a positive effect on the $A D M E(T)$ parameters or with the promoiety masking a certain part of the drug's chemical structure that is responsible for its cumbersome pharmacokinetics. But the term 'prodrug' can also comprise compounds lacking a functional moiety that is essential for the drug's activity. Furthermore, a promoiety does not necessarily have to make up an extensive part of the prodrug - sometimes it can be just as little as a carboxyl group.

\section{First prodrugs - A concept that was made use of before its conceptual existence}

Although the term "prodrug" was only introduced in the late 1950s, some drugs introduced into medical practice before then can also be classified as prodrugs.

Acetanilide seems to be the first prodrug reported, in the $19^{\text {th }}$ century, as a pain reliever. However, its activity was only afterwards found to be a result of its biologically active parent compound, i.e. paracetamol, also called as acetaminophen in the United States. ${ }^{4}$ Acetanilide is actually metabolized in the liver, by the cytochrome P450 enzymes, which introduce a hydroxyl group to the phenyl ring of the molecule, thus resulting in the active drug. ${ }^{5-7}$

Despite the success of acetanilide, the first prodrug intentionally developed is most likely methenamine - or hexamine (Schering, 1899) for the treatment of urinary tract infections. ${ }^{8,9}$ Cleavage of methenamine provides the antibacterial formaldehyde, which is corrosive to the gastrointestinal tract and causes inflammation and ulceration of the mouth, esophagus, and stomach. ${ }^{10}$ This approach therefore allowed the delivery of formaldehyde directly into the urinary tract by acid hydrolysis of methenamine in the bladder $^{11}$, making methenamine an early example of a site-selective prodrug. ${ }^{6,12}$

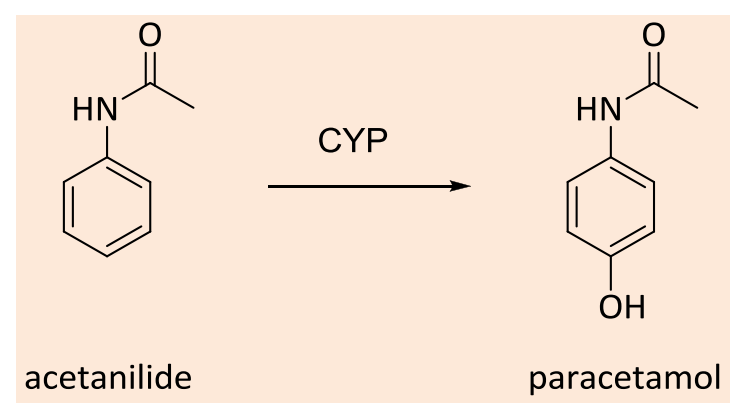

Scheme 1. Acetanilide is oxidized in the liver by cytochrome P450 enzymes (CYP) affording the active compound paracetamol

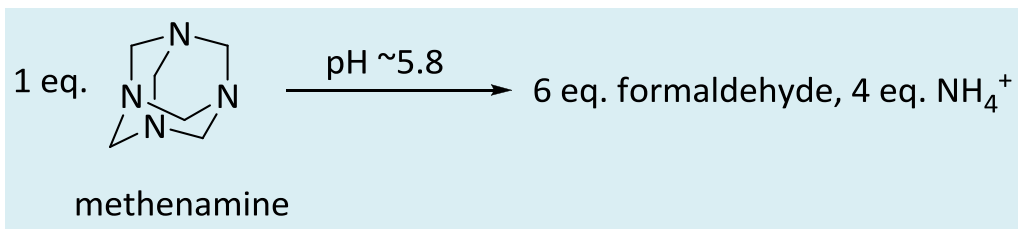

Scheme 2. Methenamine sets free six equivalents of the bactericidal formaldehyde in the acidic milieu of the bladder

The well-known and widely used drug Aspirin, i.e. acetylsalicylic acid, was antipyretic, analgesic and anti-inflammatory synthetized by Felix Hoffman (Bayer, 
Germany), and put into market in $1899 .^{13}$ Less irritating than sodium salicylate, Aspirin is hydrolyzed in the intestinal wall, liver and blood to salicylic acid (salicylic acid, of course, is best known for its use in skin-care products). ${ }^{14,15}$ Nevertheless, classifying Aspirin as an actual prodrug is still debatable. As it is an irreversible inhibitor of cyclooxygenase (COX), which is involved in the formation of prostaglandins and thromboxanes, salicylic acid (weakly) reversibly inactivates this enzyme. ${ }^{7,16}$ Despite this, the advantage of using aspirin is undeniable: it overcame the limitation of the use of the biologically active parent compound, which is somewhat corrosive for oral administration.

Many decades later, in 1935 - still before the conceptual introduction of prodrugs Bayer developed the first sulfa drug called Prontosil. This opened a new era in medicine and introduced an important new class of antimicrobial agents. ${ }^{17}$ Similar to acetanilide, Prontosil is also an example of a fortuitous prodrug, as its antibacterial activity was later attributed to para-aminophenylsulfonamide (sulfanilamide) after metabolization of Prontosil by azo reductase enzymes. ${ }^{8,18}$

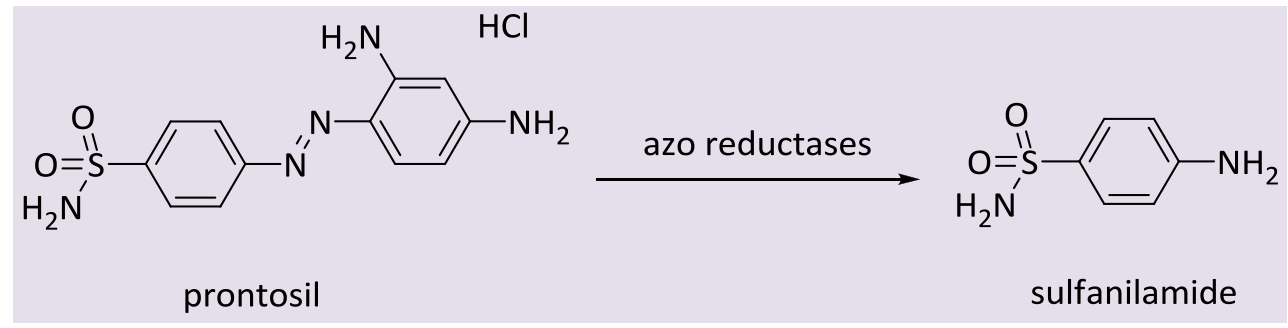

Scheme 3. The enzymatic conversion of the prodrug prontosil to the active drug sulfanilamide

In the 1950s, Parker-Davis Company modified the antibiotic compound chloramphenicol aiming at improving its water solubility by esterification with succinic acid (chloramphenicol sodium succinate) permitting its intravenous, and intramuscular administration for the first time. Countering the bad taste of the drug, chloramphenicol palmitate was developed. The palmitate ester is cleaved in the gastrointestinal tract prior to absorption so that the high oral bioavailability of the active drug is not affected. ${ }^{19-21}$

The prodrug approach has been increasingly used during the last decades, and has overcome different issues limiting the therapeutic use of marketed drugs, as well as drug candidates. Also it represents an effective lifecycle management opportunity of several pharmaceutical products. ${ }^{22}$

For one, it has been widely applied to circumvent drawbacks associated with poor water solubility of drugs since the 1950's with the synthesis of the sodium succinate salt of chloramphenicol commented above, particularly by introducing hydrophilic functional moieties in the molecules. ${ }^{4}$

\section{Increasing water solubility}

In general, enhanced solubility in water of highly lipophilic drugs having a hydroxyl group may be achieved by incorporating esters that bring a charge to the molecule such as hemisuccinates, phosphates, dialkylaminoacetates and amino acid esters (Fig. 1). In the case of compounds having a carboxyl group, ester or amide formation with the choline alcohol/?dimethylaminoethanol or amine of an $\alpha$ amino acid has been used successfully for this purpose. $^{23,24}$ 


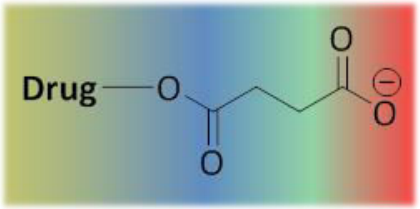

hemisuccinate

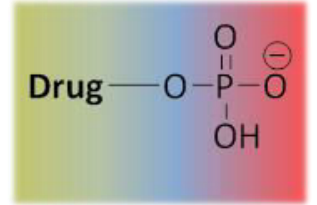

phosphate

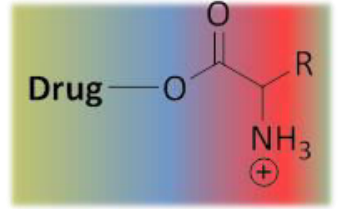

amino acid ester

highly lipophilic

highly hydrophilic

Figure 1. charged esters for improving water solubility

Phosphate ester prodrugs are common prodrugs developed for overcoming this limitation, and there are many examples of marketed drugs in which phosphate ester prodrugs were used. Phosphate derivatives go through biotransformation by endogenous phosphatases located in different parts of the organisms, e.g. alkaline phosphatases from the intestine, plasma and liver. ${ }^{18,24,25}$

For instance, fosamprenavir is a phosphate ester of the HIV protease inhibitor amprenavir. It has shown to be 10 -fold more water soluble, and reduce the required dosage regimen from 8 times to only twice daily compared to its parent active compound (the benefit of the enhanced patient compliance will be discussed in this paper under the section "the impact of the prodrug strategy on current treatments"). ${ }^{26,27}$

Other water soluble phosphate prodrugs include, e.g., estramustine (anticancer), prednisolone (anti-inflammatory, antiallergic), fludarabine (antiviral) and propofol (anaesthetic) phosphates; fosfluconazole (antifungal), and fosphenytoin (anticonvulsivant). ${ }^{24}$

The non-steroidal anti-inflammatory Sulindac also had its water solubility improved by its oxide prodrug, which is reversibly reduced to the active sulphide form after oral absorption. ${ }^{28}$

\section{Enabling the passage through cell-membranes ( $\&$ impeding back- diffusion)}

\subsection{Enhancing the absorption from the} GIT

There are several routes via which a drug molecule can be administered (e.g. oral, rectal, intravenous, intramuscular, ocular, topical, nasal, etc.), but the oral route is the most common and desirable one, ${ }^{29}$ although less efficient in terms of absorption compared to the others. ${ }^{30}$

For an orally administered drug molecule to reach the bloodstream, it must go across the (phospholipid bilayer) epithelial cell membrane along the gastrointestinal tract from where it will be delivered to the target tissue(s). Absorption takes place by passive or facilitated diffusion or carrier-mediated active transport (Fig. 2), the type of method of crossing the cell membrane basically depending on the chemical and physical properties of the drug molecule, i.e. size and structural features, degree of ionization, relative lipid solubility of ionized/non-ionized forms, and binding to serum and tissue proteins. ${ }^{31}$ 


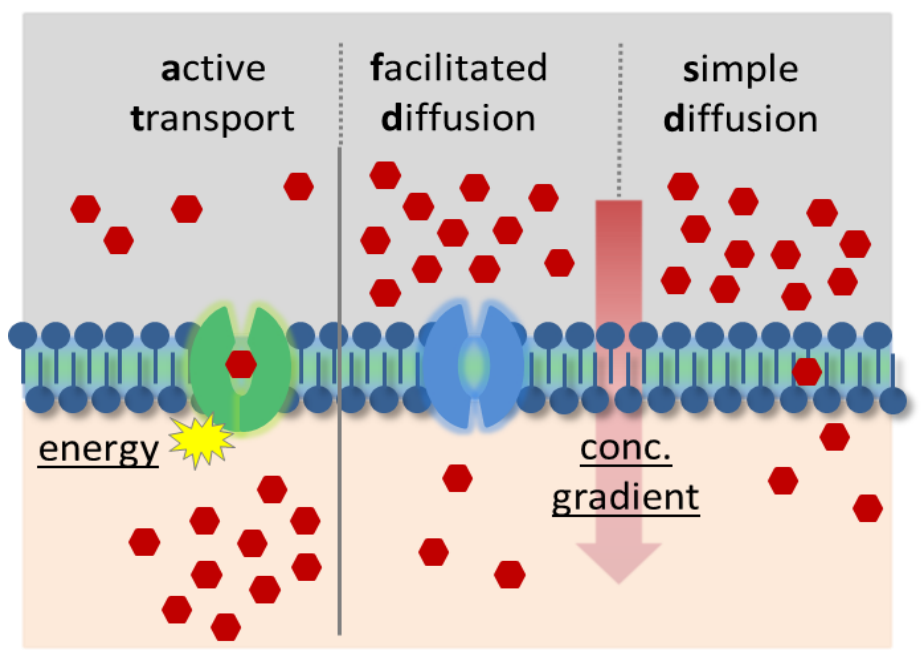

Figure 2. Membrane drug transport processes: passive $(\mathrm{sd}, \mathrm{fd}$; the driving force is the concentration gradient; in $\mathrm{fd}$ the diffusion is assisted by integral membrane proteins, e.g. channels, carrier proteins which do not consume cellular energy); active (at; carrier-mediated; the driving force is the either direct or indirect consumption of ATP)

Passive diffusion, which occurs when a higher concentration of the drug is at one side of the membrane, is the most common one. $^{32}$ Gases, as for instance oxygen and carbon dioxide, hydrophobic molecules and very small, polar but uncharged compounds can diffuse freely across cell membranes. Often, however, active drug molecules do not comply with these conditions. Therefore, many drug candidates have failed in clinical trials due to their undesirable pharmacokinetic properties, inter alia poor absorption, ${ }^{33}$ and the prodrug strategy has often been used to obtain improved oral bioavailability of poorly absorbed compounds. ${ }^{13,34}$

Esters are the most common prodrugs designed for enhancing lipophilicity of water soluble drugs (especially those comprising ionizable groups within the molecule, such as carboxylic acids and phosphates, Fig. 3), and, as a result, their passive permeability through the (lipid bilayer) epithelial cell membrane. After absorption, esterases found in several parts of the organism promptly hydrolyze the ester moiety, and the bioactive parent drug is released. It should be noted, however, that there should be a balance between the aqueous and lipid solubility of the prodrug, as it must also be water soluble enough to be dissolved in the gastrointestinal aqueous media. ${ }^{15,30}$ This balance between aqueous and lipid solubility is described by the partition coefficient $P$ of a compound, which describes the ratio of concentrations of the compound in a two-phase-system, in the pharmaceutical sciences this is most commonly 1-octanol and water. The value is generally given in a logarithmic representation as logP-value. Consequently, $\log P>0$ means that more of the compound is dissolved in the lipophilic 1-octanol-phase than in the aqueous phase and vice versa. According to Lipinski's rule of five it has been established that poor absorption and permeation is more likely when the drug exhibits a $\log P$ greater than five. ${ }^{35}$ It is generally accepted, that a $\log \mathrm{P}$ in the range of $0-3$ is optimal for gastrointestinal absorption by passive diffusion. ${ }^{36}$ 


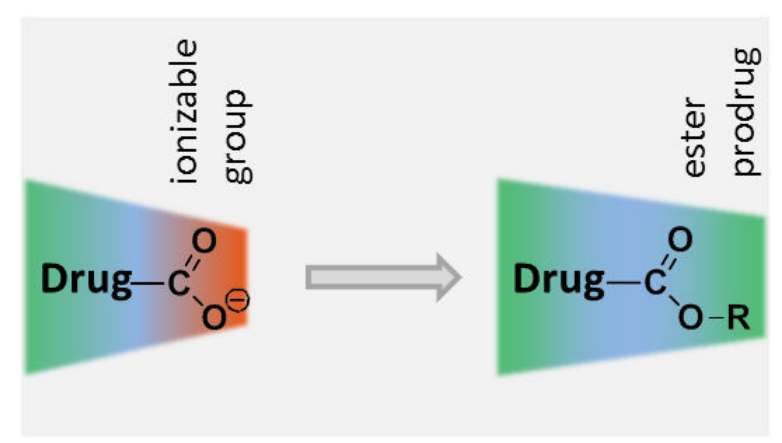

Figure 3. Masking a carboxylate by esterification has a high influence on the polarity/electron density distribution throughout the molecule

A remarkable example that can be cited is the enalapril, which is an ester prodrug of enalaprilat, an ACE (Angiotensin converting enzyme) inhibitor used in the treatment of hypertension. After oral administration, $60 \%$ of the enalapril is absorbed, the ester moiety is then hydrolyzed, and $40 \%$ of the active form enalaprilat is released. In comparison, absorption of the active drug enalaprilat per se was as low as $3 \%{ }^{4,37}$

Several other examples can be cited, where esterification of an ionizable functionality in the drug molecule leads to enhanced permeability of the active parent compound, such as the Ethylester of Oseltamivir carboxylate (a selective inhibitor of influenza $A$ and $B$ neuraminidase), which is rapidly and well absorbed, increasing the oral bioavailability from $5 \%$ to $79 \% .{ }^{38}$

While the passive transcellular transport in simple diffusion is generally neither saturable nor subject to inhibition or stereospecific, it requires the drug to meet strict physicochemical parameters, mainly to be seen in the strong lipophilicity dependence. ${ }^{39}$ Many drugs, though, which do not match the criteria for passive intestinal uptake, are still orally bioavailable at unexpectedly high percentages. Even though first pass effects and intestinal efflux must be taken into consideration when it comes to oral availability, high values still suggest either high rates in diffusion or its counterpart - the carrier-mediated transcellular transport. The latter is operated by e.g. nutrient transporters which are present in the epithelial cell membranes in the small intestines.

In valaciclovir and valganciclovir the hydroxyl functions of the antiviral drugs aciclovir and ganciclovir are esterified with the amino acid valine. When first developed for improving water solubility and thus permitting oral administration, it was noticed that the plasma levels of aciclovir strongly depended on the structure of the amino acid used for esterification. The stereochemistry of the amino acid also had a strong impact on the absorption of the prodrug, which is highly increased in the case of I-val. Thus, the involvement of a transporter was presumed. ${ }^{40}$ This was proven later, as these prodrugs are actually substrates of small peptide transporters (PEPT1) distributed throughout the intestine epithelium. ${ }^{41}$ Other groups of amino acid ester prodrugs, e.g. the $5^{\prime}$-O-I-Valyl ester of the antiviral didanosine, ${ }^{42}$ and the d-phenyl glycine ester of the antiparkinsonian dopamingenic precursor drug I-dopa ${ }^{43}$ are also substrates for this particular type of transporter. ${ }^{44}$

A prodrug of the anticonvulsant and antihyperalgesic agent gabapentin (a structural analogue $\gamma$-aminobutiryc acid GABA), gabapentin enacarbil, can also be carried by two different transporters located in the intestine epithelium, i.e. monocarboxylic acid transporter-1 (MCT1) and sodium-dependent multivitamin transporter (SMVT), and exhibits enhanced absorption and bioavailability vis-à-vis its parent compound. ${ }^{24,45}$ 
Thanks to the increased understanding of the role of such nutrient membrane transporters over the past decades, significantly improved absorption of bioprecursors via the oral route compared to their parent active compound has been achieved. ${ }^{46,47}$ According to Dobson and Kell, 2008, carrier-mediated uptake of drugs seems to be a more ordinary mechanism than generally presumed, so that it would not be an exception compared to transport across biological membranes by means of passive diffusion. ${ }^{48}$

\subsection{Allowing for simple diffusion into target cells/tissues}

As mentioned, prodrugs may be developed for increasing lipophilicity of the molecule, which facilitates passive permeability through the cell membrane, and thus drug delivery. ${ }^{30}$

Especially when it comes to charged molecules, e.g. nucleoside monophosphates and amino drugs (which tend to ionize under physiological conditions), the prodrug approach has been used for designing molecules to mask the charged moiety with a lipophilic, degradable group. After more easily penetrating through cellular membranes (or the blood-brain barrier - BBB) due to the lower polarity of the prodrug, the lipophilic mask is enzymatically and/or chemically cleaved. The compound is therefore trapped inside the cells, as backdiffusion across the cell membrane to the extracellular environment is prevented by the regained charge..$^{49-51}$

The BBB serves as a nearly impermeable diffusion barrier for hydrophilic compounds between the systemic circulation and the central nervous system (CNS). Only small and highly lipophilic compounds can diffuse freely across the membranes, though they only reach their target if they are no substrate of the active efflux transporters. There are, however, strategies for drugs meant to unfold their activity in the brain to overcome this barrier. The generation of simple ester prodrugs for masking high polarity (as discussed above) can enable drugs to cross this barrier simply by rendering the active compound more lipophilic. However, this 'general lipophilization also allows for enhanced uptake in other tissues. This might lead to toxicity issues. Together with the higher affinity of lipophilic compounds for binding to plasma proteins, also the efficiency of the drug at the target sites is decreased. ${ }^{52}$ Still, there are successful examples of simple ester prodrugs with highly increased BBB penetration compared to the active compound, the most prominent possibly being heroin, the diacetate of morphine.

In contrast to simple ester prodrugs, which are activated in a single step, Chemical drug Delivery Systems (CDS) typically require sequential bioactivation steps. Although the definition of CDS seems to adhere to the wide concept of prodrugs this article illustrates, one might say it constitutes more elaborate drug-promoiety(ies) conjugates more profoundly integrating structuremetabolism relationships. The conjugates themselves can be considered comparable to soft drugs. They comprise a lipophilic moiety which ensures the prodrug's penetration of cell membranes and they are susceptible to rapid metabolic processes, e.g. oxidation. This metabolic reaction affords a more polar molecule, which is not able to re-diffuse out of the target cell or tissue ('lock-in', Fig. 4). The drug - still in an inactive conjugate form is thus trapped inside e.g. the CNS. There, the drug will subsequently be set free by other enzymatic or chemical reactions.

Prominent examples use the 1,4dihydrotrigonelline - trigonelline-system as targetor moiety responsible for sitespecificity and trapping. This approach can not only be used for CNS-delivery of polar drugs. It can also allow for the trapping of highly lipophilic drugs inside the CNS, which would otherwise readily re-diffuse out of the target tissue. ${ }^{52,53}$ 


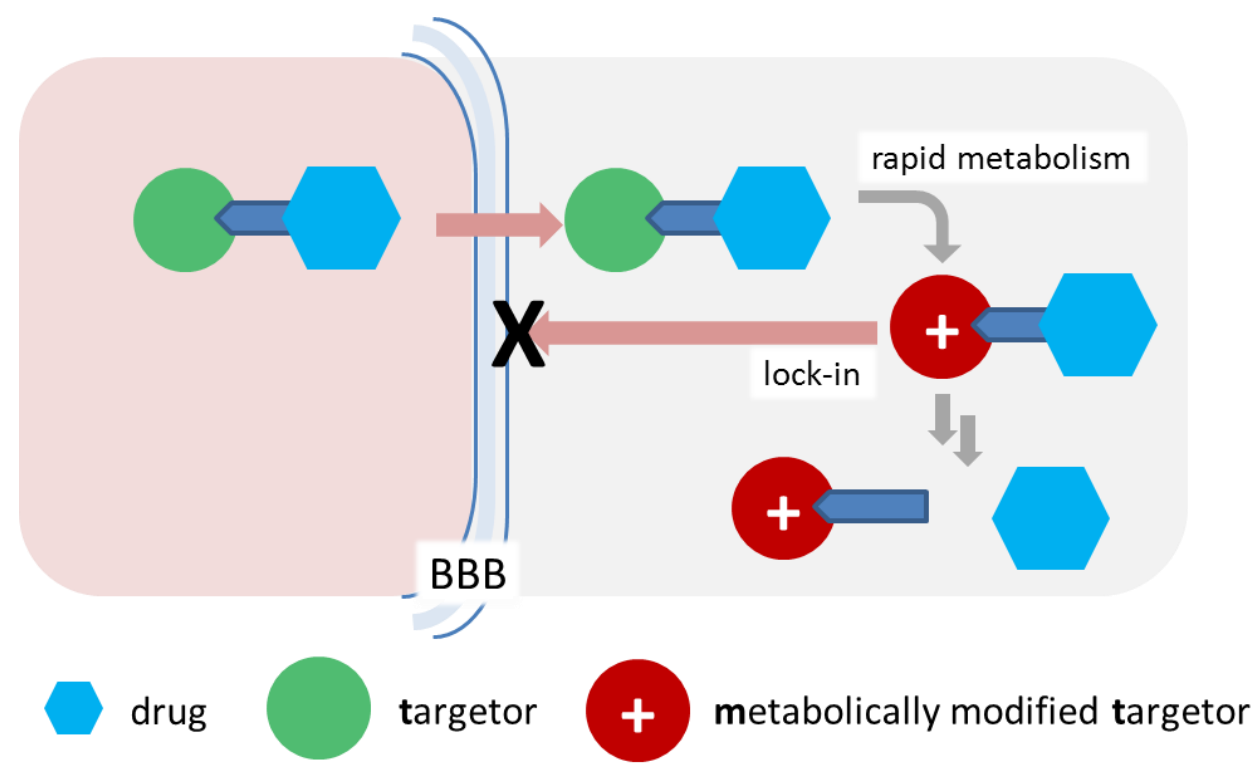

Figure 4. Basic concept of the Chemical Delivery System for CNS therapeutics; after penetrating the blood brain barrier the targetor is metabolized into a charged/highly polar residue thus preventing re-diffusion, subsequently the promoiety is cleaved

\subsection{Permitting active uptake from systemic circulation}

Passage though cell membranes can not only be achieved by enabling simple diffusion via lipidization. Another approach is to make use of active transporters inside the membrane. For instance, by attaching a promoiety or simply a functional group to the active compound that provides for the entity to be recognized by nutrient transporters, such as those for amino acids, the impermeability of the BBB no longer applies.
One prominent example is Levodopa, which is used in the therapy of Parkinson's Disease. It is actively transported via the BBB by LAT1 (large neutral amino acid transporter $1)^{54}$ since - being an I-amino acid (I-dopa) - it resembles the naturally occurring aromatic amino acids tyrosine, phenylalanine resp. It sets free the active compound dopamine, which itself cannot cross the BBB, by the action of decarboxylases (Scheme 4). ${ }^{55,56}$ Thereby, since back-diffusion or -transport is precluded, the dopamine gets "trapped" inside the brain tissue.

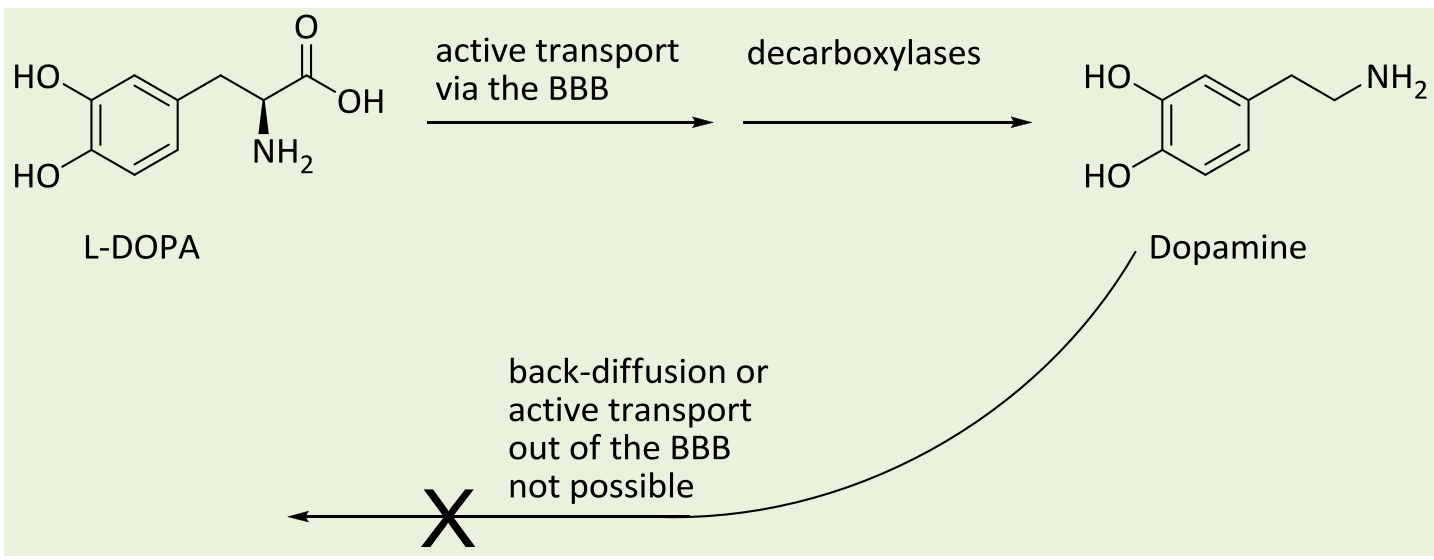

Scheme 4. L-DOPA 
In cancer therapy the development of multi drug resistance (MDR) poses an immense problem which amongst other causes is evoked by efflux systems. One basic approach to antagonize this is to increase the 'influx' and thus the cellular accumulation of the drug. Tumor cells as well require nutrients so their (over)expression of related transporters can be exploited by making use of the very same concept just described. There have been various attempts to increase the intracellular concentration of an anticancer compound by active uptake - e.g. via amino acid transporters - to simply overrule the kinetics of efflux and thereby enhance the drug's effect at the site of action. $^{57,58}$

The concept of active uptake is predetermined to differentiate between "uptake-targets" meaning different organs or cell types that express distinct carrier proteins or receptors. Thus, this concept can be used for a somewhat targeted drugdelivery, which will be discussed in the next chapter.

\section{Lowering Toxicity and adverse- effects - Prodrugs for site-specific activation and targeted drug- delivery}

The therapeutic index is a crucial parameter in the evaluation of a drugs merit. It describes the range between a drug's efficacious, beneficial concentration and the concentration effecting toxicity. The toxicity can be caused by metabolites of the drug but also by the drug itself interfering with another or multiple targets (off-target activity). Moreover, if the drug is intended to manipulate (host) cell-own processes in a distinct group of target cells (e.g. cancer cells), toxicity is induced by systemic distribution of the drug so that it affects the same cell-own processes in healthy cells. Strategies to evade such causes for adverse effects include the development of prodrugs which are predominantly activated in the target cells (site-specific activation) and systems which allow for the targeted delivery of the drugs.

One approach of using prodrugs for targeting drugs to cells of a specific organ is the HepDirect prodrug system. The treatment of chronic liver disease, such as Hepatitis B or C and hepatocellular carcinoma, often employs nucleoside analogues which interfere with DNA/RNA synthesis. To be active, the nucleoside analogues have to first be metabolized to yield the corresponding nucleoside triphosphates. Since the efficiency of this metabolism is often low, several concepts have been developed to deliver the highly charged nucleoside monophosphates into the cells. $^{59}$ The HepDirect prodrug system combines masking the charges of nucleoside monophosphates with targeting of hepatocytes. The latter is achieved by the chemical structure of the promoiety: for its cleavage it has to be oxidized by a cytochrome P450 isoenzyme family which is predominantly expressed in the liver (scheme 5). ${ }^{60,61}$ Two such agents are currently in clinical trials: pradefovir, the HepDirect prodrug of the anti-Hepatitis $\mathrm{B}$ drug Adefovir, and MB07133, a HepDirect derivative of the anticancer nucleoside analogue Cytarabine. ${ }^{62}$ These liver targeted prodrugs drastically reduce toxicity e.g. associated with the drugs action on the kidney ore bone marrow, where these prodrugs are only activated to a very minor extent. 


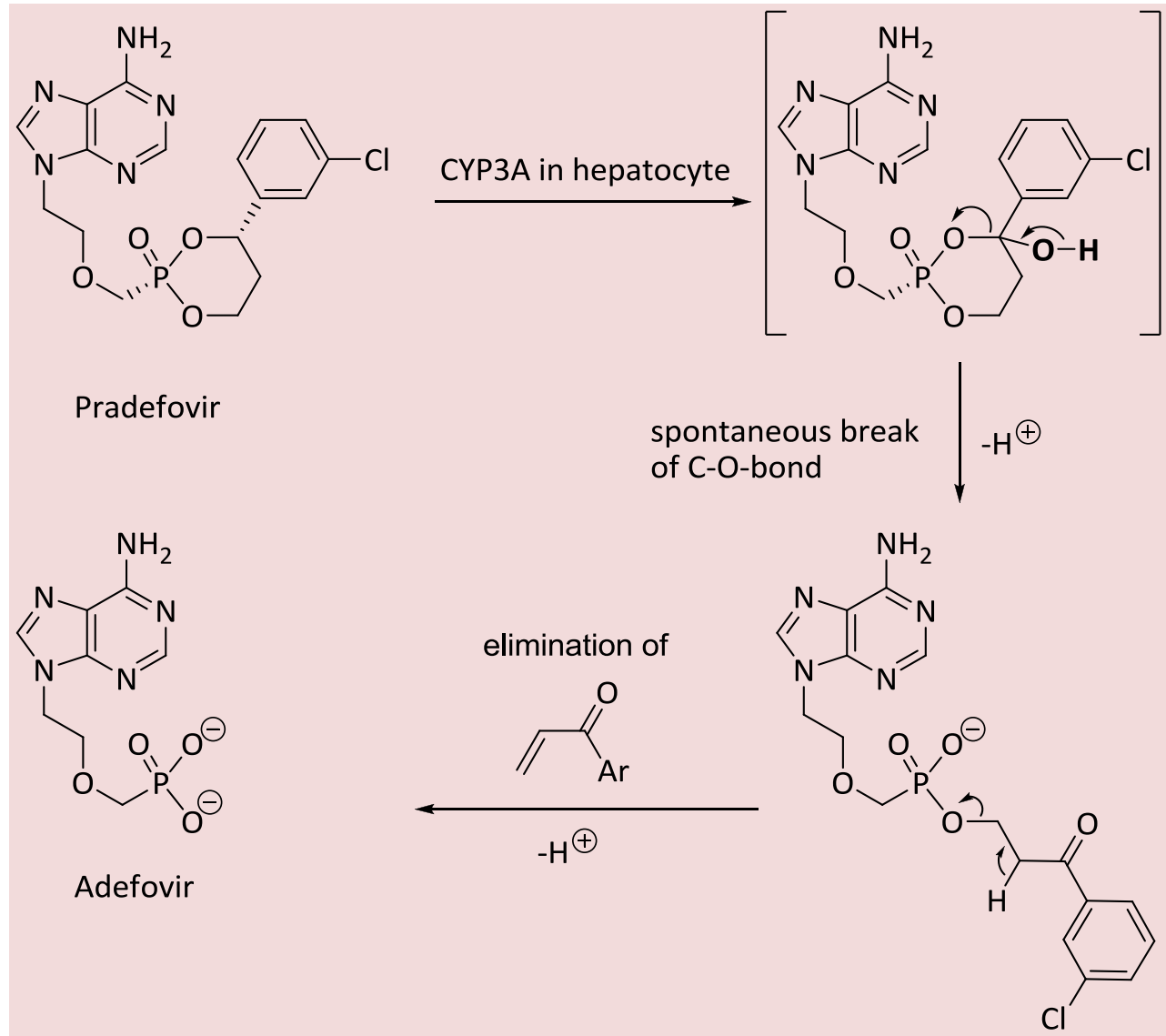

Scheme 5. The HepDirect prodrug system; mechanism of activation of pradefovir via oxidation in hepatocytes resulting in the release of adefovir

Moreover, for antiviral therapy, viral enzymes can be used to activate of a prodrug. This way, the drug will only be released in those cells that are infected with the virus. Advantageously, this allows for the avoidance of adverse effects which result from the drug's action on host-cellular targets. Aciclovir makes an example of such a "cell-specific" prodrug. Although the compound itself, of course, cannot distinguish between cells, its metabolic activation only takes place in cells infected with the herpes viridae since the viral thymidine kinase is required for its phosphorylation (Figure 5). ${ }^{63}$

Other properties that distinguish healthy cells from diseased cells can be listed under "the chemical state of the cell", e.g. pH, concentration of reducing or oxidizing agents etc. The chemical environment inside a cancer cell hugely differs from the one inside a healthy cell. For example, reactive oxygen species (ROS) are higher in concentration in cancer cells of various types. ${ }^{64}$ This can be used for targeted drug release, e.g., by linking an anticancer agent with a promoiety, which masks the cytotoxicity of the compound while being attached to it and which sets it free via a chemical reaction involving an oxidation step. This way, the cytotoxicity is predominantly exposed in the target cells and the side effects of the parent drug that are accounted for by its action in healthy cells can be dimmed. Aryl boronic acids and esters thereof can be cleaved by oxidation, e.g. by treatment with $\mathrm{H}_{2} \mathrm{O}_{2}$ - an important ROS that can be found in cancer cells. Inspired by the $\mathrm{H}_{2} \mathrm{O}_{2}$-activated fluorescent probes of Chang, ${ }^{65}$ Peng's group has developed aryl boronic acid/ester-masked nitrogen mustards, which have proven to be nontoxic in the absence of $\mathrm{H}_{2} \mathrm{O}_{2}$ and set free the DNA-cross 
linking/alkylating agent in tumor cells. ${ }^{66}$ Nitrogen mustards are important chemotherapeutics in cancer therapy. The nucleophilic attack of the electron lone pair of the nitrogen atom at the chloride- substituted carbon atom leads to the formation of the aziridinium ion, which is highly reactive (Scheme 6 ). This then leads to interstrand crosslinking of DNA, which causes replication arrest and cell death.
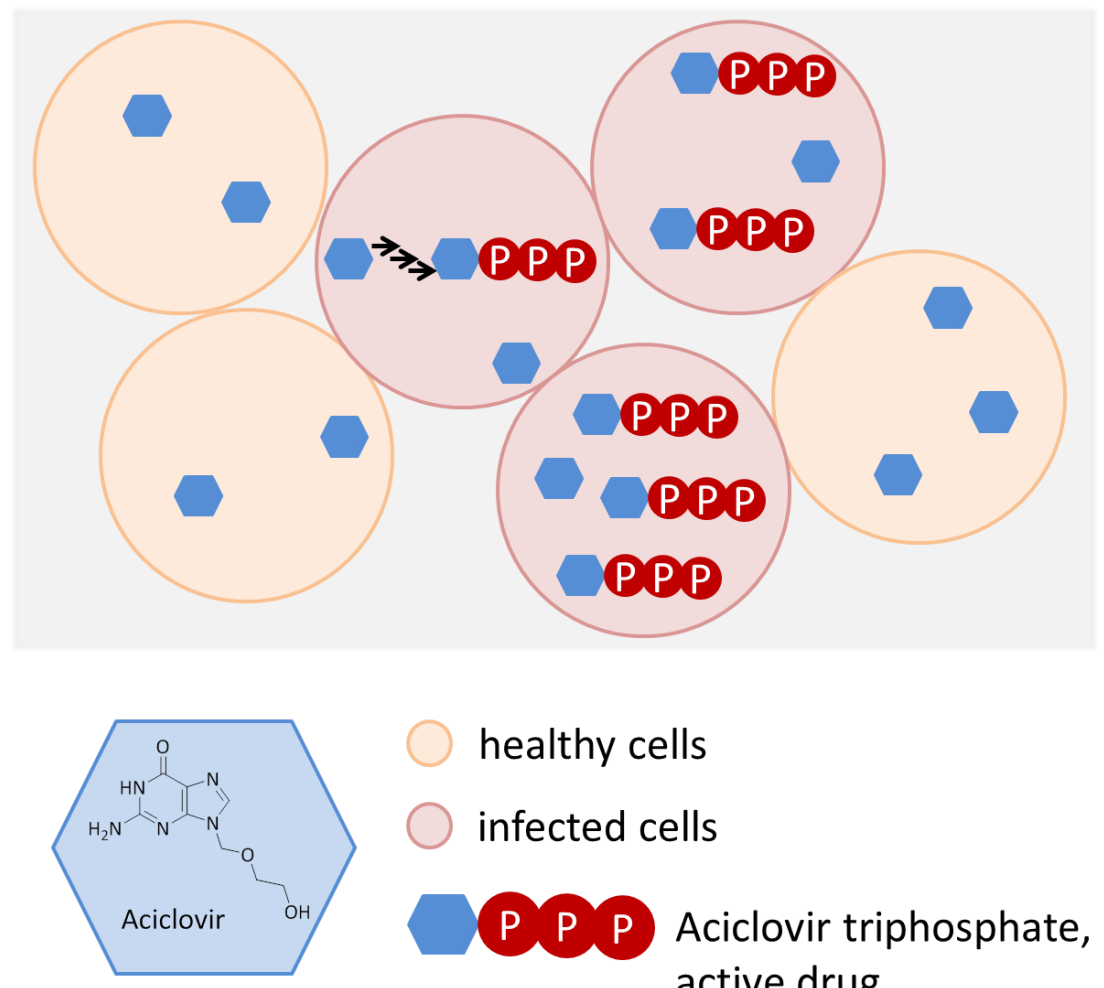

healthy cells

infected cells

P P Aciclovir triphosphate, active drug

Figure 5. Site-selective activation of Aciclovir

In the boronic acid/ester prodrugs of a nitrogen mustard, the nitrogen in the ammonium form lacks the lone pair, so the reaction yielding the aziridinium ion is excluded. Only by the $\mathrm{H}_{2} \mathrm{O}_{2}$-induced cleavage of the C-B-bond, the lone pair at the nitrogen atom is regained after elimination of the chinone methide (Scheme 7). ${ }^{66}$ 
$\mathrm{Cl}$<smiles>CN(CCI)CCC(C)(Cl)CCl</smiles>

Chlormethine (Mustine, ${ }_{\text {HN2) }}$

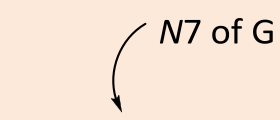

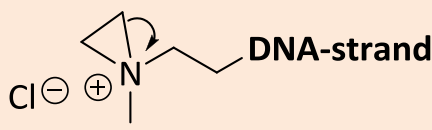

2nd aziridinium ion formation

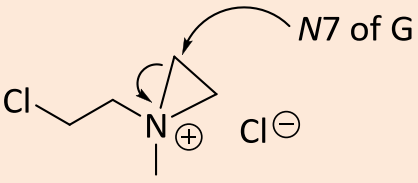

aziridinium ion alkylation at $N 7$ of guanine bases of the opposed DNA-strand

DNA-strand DNA-strand

interstrand crosslinked DNA

Scheme 6. The mechanism of action of nitrogen mustards as anticancer agents; formation of the aziridinium ion via nucleophilic displacement of the chloride; the DNA interstrand crosslinking leads to replication arrest and cell death<smiles>[R]OB([R6])c1ccc(C[N+](C)(CCCl)CCCl)cc1</smiles><smiles>[R]OB([R6])Oc1ccc(C[N+](C)(CCCl)CCCl)cc1</smiles>

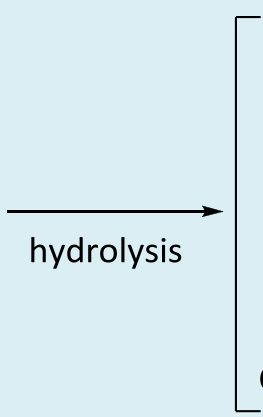<smiles>C[N+](CCCl)(CCCl)Cc1ccc([O-])cc1</smiles>

boronic ester prodrug<smiles>CN(CCCl)CCCl</smiles>

Scheme 7. $\mathrm{H}_{2} \mathrm{O}_{2}$-induced prodrug of a nitrogen mustard for release in cancer cells 
As noted above, the intracellular media of cancer cells can be differentiated from that inside healthy cells resulting in the advantage of site-specific chemical activation of anticancer prodrugs. Additionally, it is known that certain glycosylases, for instance betaglucuronidase, and peptidases, as plasmin or prostate-specific antigen, are expressed in the extra cellular space of tumors in comparatively high concentrations. By attachment of a promoiety to a cytotoxic compound that can be cleaved by the action of these enzymes, a site-specific activation of the prodrug inside the tumor tissue can be observed leading to lowered toxicity in healthy tissue. ${ }^{67-69}$ Further development of this approach led to the antibody directed enzyme prodrug therapy (ADEPT), where a detoxified prodrug of a cytotoxic agent is applied in combination with an antibodyenzyme conjugate. By directing the conjugate to tumor specific antigens, the enzymatically triggered activation of the prodrug takes place inside the tumor tissue, thereby enabling a somewhat specific cytotoxic therapy (Fig. 6). ${ }^{70}$

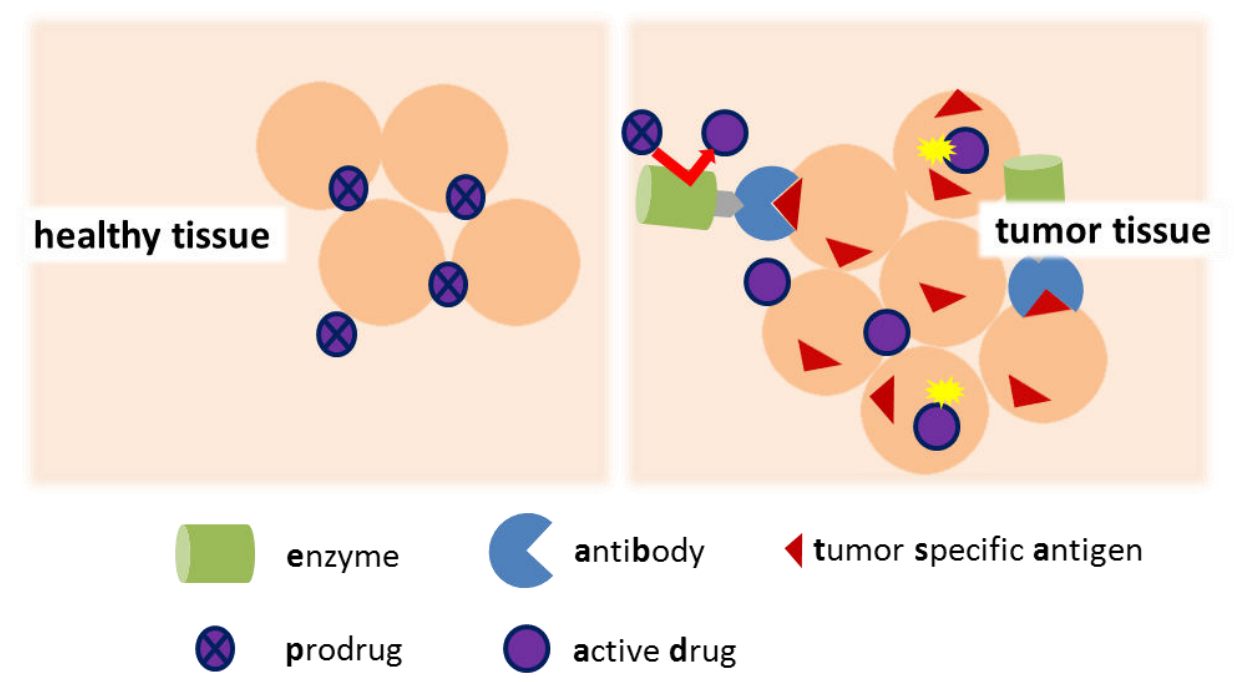

Figure 6. Illustration of ADEPT; the ab-e conjugate is directed to and accumulated in tumor tissue via the ab-tsa interaction; after clearance of the conjugate from systemic circulation the prodrug is administered; it is specifically activated in tumor tissue via the enzymatic reaction, thereby, healthy tissue remains unaffected

In the case of the cytotoxic phenolic nitrogen mustard, phosphate esters, glutamic acid carbonates/carbamates and glucuronides have been employed as promoieties. These promoieties can be efficiently cleaved by alkaline phosphatase, bacterial carboxypeptidase G2 and glucuronidase, respectively, to release the cytotoxic agent. ${ }^{71-73}$

5-Fluoro uracil (5FU) - a modified nucleobase - is another drug that is widely applied in anticancer chemotherapy. It acts by inducing replication arrest. Its prodrug Capecitabine is converted to $5 \mathrm{FU}$ - after the action of carboxyesterases and cytidine deaminase - by thymidine phosphorylase. ${ }^{74}$ This enzyme shows high activity in certain tumor cells, thereby enhancing the relative concentration of $5 \mathrm{FU}$ compared to healthy cells. ${ }^{75,76}$

A recently developed strategy to deliver 5FU only to a certain group of cells uses the aptamer-mediated drug delivery. Aptamers are nucleic acids which either bind a specific target molecule or are specifically bound to a target protein e.g. a receptor. Hahn's group developed an aptamer which is specifically bound by the human interleukin- 6 receptor. Binding is followed by internalization and transport to the lysosome. Incorporation of 
5-fluoro uracil deoxyribose (5FUdR) into the aptamer by replacement of uridines resulted in cell cycle arrest of those treated cells, which expressed the receptor. It is assumed that in the lysosome the aptamer is degraded by lysosomal nucleases yielding $5 \mathrm{FUdR}$, which in turn is actively transported out of the lysosome. After phosphorylation, it strongly inhibits thymidylate synthase, thereby ultimately leading to cell death. ${ }^{77}$

\section{Increasing metabolic stability \& enhancing a drugs half-life}

Drugs can be substrates for fast metabolic processes. Hence, a given drug can be cleared quickly from circulation - which is unfavorable, if not meant to be a shortacting, soft drug - and thus require multiple dosing per day. Rapid metabolism (first pass effects) can even drastically decrease the drug's oral bioavailability. By application of the prodrug-concept those functional groups that are essentially responsible for the metabolic 'breakdown' of a drug (more precise would be the term 'inactivation') can be masked. In this manner, the promoiety acts as a 'protecting group' here. Slow in vivo conversion of this promoiety-drug-conjugate to the active compound can then result in a sustained drug level. For example, phenolic hydroxyl groups are rapidly conjugated in phase II metabolic processes (Oglucuronidation). Their masking as alkyl carbamates or carbonates has proven to be an effective strategy to counter metabolic instability of drugs containing such functionalities, as is the case in bambuterol (the biscarbamate prodrug of terbutaline, a bronchodilator; Fig. 7).

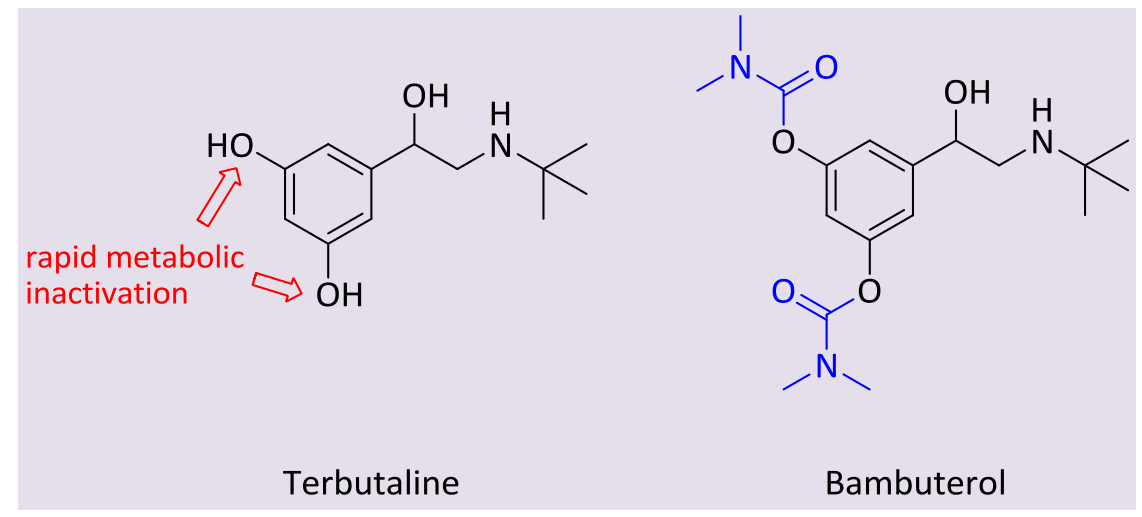

Figure 7. Structures of the dihydroxyphenyl compound Terbutaline and its biscarbamate prodrug bambuterol

Since in the intestinal wall and liver, unspecific carboxyesterases are present in quite high concentrations, simple esterification of the phenolic hydroxyl groups of terbutaline did not result in presystemically stabile prodrugs. The carbamate, however, is not cleaved by these enzymes. It was shown to be slowly cleaved by unspecific cholinesterases while at the same time inhibiting their action. ${ }^{78}$ Hence, not the entire absorbed compound is directly exposed to the inactivating metabolism; moreover, the active substance is slowly released making once-daily dosing possible, much preferable to the three daily dosages required when administering the parent compound, terbutaline..$^{79-81}$ 


\section{The impact of the prodrug strategy on current treatments \& what the future holds}

The anti-HCV agent Sofosbuvir is a recent example of the huge success of a prodrug. As mentioned above, nucleoside analogues exhibit great potential in the therapy of viral infections and cancer by interfering with the replication machinery. A critical parameter for the activity of a nucleoside analogue is the kinetics of its phosphorylation, ultimately yielding the triphosphate as the active compound - that is the nucleoside analogue itself being a prodrug. Often, however, the first, highly specific phosphorylation step is low in rate. Moreover, the dependency of the nucleoside analogue being activated by kinases can lead to resistances. Since nucleotides are unable to passively penetrate cell membranes due to their high charge and are rapidly dephosphorylated while circulating, prodrug systems masking the phosphate group have been developed. Sofosbuvir is an amidate prodrug (based on the ProTide-concept developed by McGuigan) of the monophosphate of a 2'deoxy-2'-fluoro-2'methyl uridine analogue. The negative charges of the phosphate group are masked by 1) esterification with phenol and 2) the amidate group consisting of an amino acid ester. The nucleotide is set free by firstly the action of cellular carboxyl esterases. The cleavage of the amino acid carboxyl ester then initiates a cyclization, displacing the phenol. After hydrolysis of the intermediate a second enzymatic reaction yields the nucleotide, which is then further phosphorylated (Scheme 8). ${ }^{4,82}$

When orally administered, the prodrug is directly gated from the GIT to the liver by the portal vein. Since in the hepatocytes the concentration of carboxyl esterases is quite high, the first step of the nucleotide- delivering metabolism of the prodrug immediately appears in these cells. This is why Sofosbuvir is not only a nucleotide prodrug that facilitates the diffusion of the monophosphate through the cell membrane but also targets the drug to hepatocytes, the very cells infected with $\mathrm{HCV}{ }^{83},{ }^{84}$ The FDA approved Sofosbuvir in 2013. It shows a high cure rate: clinical studies indicated that in up to $90 \%$ of chronically infected patients, the virus was no longer detectable after treatment in combination with conventional therapeutics. This is unprecedented in the treatment of chronic Hepatitis $\mathrm{C}^{85,86}$

In the case of some nucleoside analogues the first phosphorylation is not the only limited step. Meier and coworkers recently introduced a concept for bioreversibly masking the charges of nucleoside analogue di- and even triphosphates. ${ }^{87-89}$ The bypass of all three phosphorylating steps of nucleoside analogues might have great impact on future antiviral and anticancer medication. By this means, nucleoside analogues, which had been 'dropped' before, could now unfold their therapeutic potential that was hampered by failure of phosphorylation. ${ }^{90}$ By virtue of this, new agents will likely become available for the treatment against viral infections and malignant neoplastic diseases that pose major threats to society.

It should also be noted that antibiotic resistance has become the major worldwide health issue. Many efforts are currently underway to generate new antibacterial compounds. Here, prodrug strategies must be considered to include promising drug candidates, which show e.g. low metabolic stability or solubility as in Tedizolid phosphate, the phosphate prodrug of the antimicrobial agent Tedizolid, which shows activity against methicillin-resistant Staphylococcus aureus. ${ }^{91}$ 


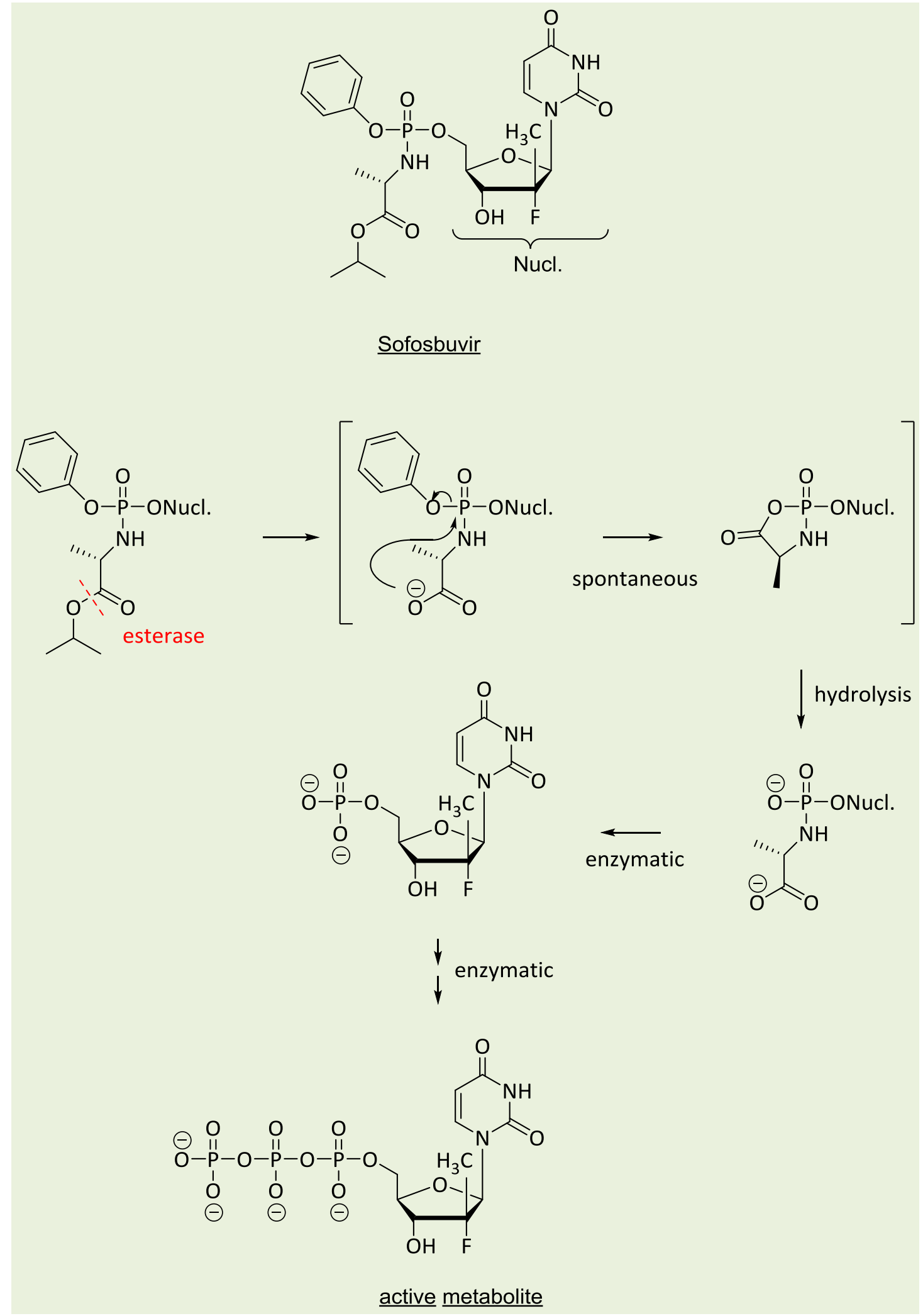

Scheme 8. Sofosbuvir and its metabolism yielding the active nucleoside analogue triphosphate

Also, as illustrated in this review, prodrug strategies can be used to, e.g., increase the influx of the drug into the target cell. Making use of transporter systems only expressed by 
bacteria, this could even result in targeted drug delivery and thereby ameliorate the drug's therapeutic index and, by the increased influx, counteract bacterial drug resistance due to efflux-pumps. Nature already makes use of bacterial transport systems for iron: Sideromycins such as albomycins consist of an iron(III)-chelating group called siderophore, which enables the compound's active uptake, and an effector part of the molecule, which provides the antibiotic activity. Since all pathogenic bacteria, gram-positive ones as well as gramnegative ones, depend on the assimilation of iron(III), they secrete iron chelators (siderophores). The iron(III)-siderophorecomplexes thus formed are actively transported into the cell by protein channels. By linking such an iron(III)-chelator with an antibiotic drug through a linker that allows for the cleavage of the two, the antibiotic efficiency of the drug can be drastically increased. It is believed that this increase is likely due to the much higher concentrations of the drug inside the cell achieved by active uptake (compared to passive diffusion). ${ }^{92-94}$

Moving on to the $M$ and $E$ of $\operatorname{ADME}(T)$, any drug that is metabolized and excreted quickly demands a strict dosing regimen. The plasma drug concentration must be kept between the minimum effective concentration and the minimum toxic concentration, which requires multiple dosing per day at distinct times. This can pose a huge burden to patients being treated with the drug in question. A lowered frequency of administration can be achieved by latentiating a drug through the attachment of a promoiety, as has been discussed for the prodrugs bambuterol and fosamprenavir. This provides relief to the patient and thereby enhances patient compliancy. Moreover, this and the prolonged effective plasma concentration of the drug counteract the development of resistances in infectious agents, which are caused by drug plasma concentrations under the therapeutic level. This strategy can be further employed in the development of new anti-infective agents, especially in cases when the active compound shows extremely short half-lives in plasma.

\section{Concluding remarks}

The continuing development of a huge number of prodrug systems reflects the great opportunities this approach offers for overcoming major drawbacks an active compound might face when applied in vivo. The definite need for new and structurally challenging drugs calls for the employment of bioprecursors that can overcome critical pharmacokinetic obstacles, thereby enhancing the chances of an active compound becoming available as a therapeutic drug. A molecule which, e.g., potently inhibits an enzyme of interest but inherently provides low drug-likeness or is simply unable to reach its site of action must not be dropped. Instead, the study of an inactive bioprecursor should be considered. This allows for a significant expansion in both the number and the variety of potential drug candidates.

The prospective development of new prodrug strategies should take pharmacogenomics into account. Since the activation of prodrugs often is initialized by host enzymatic reactions, differences in structure or in the expression of the particular enzyme directly result in varying therapeutic outcomes. Precise knowledge about the prodrug-to-drug metabolizing enzyme (and its diversity) permits one to predict whether a certain prodrug will be effective in a particular person, expressing or not-expressing this enzyme or even expressing another variation of the enzyme. This, of course, leads the way to personalized medicine, which should not stop at seeing to the variation in the drugs' targets, but must also consider the prodrugs' 'targets'. 


\section{References}

${ }^{1}$ Albert, A. Chemical Aspects of Selective Toxicity. Nature 1958, 182, 421. [CrossRef] [PubMed]

${ }^{2}$ Stella, V. J. Prodrugs: Some thoughts and current issues. Journal of Pharmaceutical Sciences 2010, 99, 4755. [CrossRef] [PubMed]

${ }^{3}$ Harper, N. J. Drug Latentiation. Journal of Medicinal and Pharmaceutical Chemistry 1959, 467. [CrossRef] [PubMed]

${ }^{4}$ Stella, V.; Borchardt, R.; Hageman, M.; Oliyai, R.; Maag, H.; Tilley, J. Prodrugs, Challenges and Rewards. Part 1. 1a ed., Springer: New York. 2007.

${ }^{5}$ Casley, W. L.; Menzies, J. A.; Mousseau, N.; Girard, M.; Moon, T. W.; Whitehouse, L.W. Increased basal expression of hepatic Cyp1a1 and Cyp1a2 genes in inbred mice selected for susceptibility to acetaminophen-induced hepatotoxicity. Pharmacogenetics 1997, 4, 283. [PubMed]

${ }^{6}$ Karaman, R. Using predrugs to optimize drug candidates. Expert Opinion on Drug Discovery 2014, 9, 1405. [CrossRef] [PubMed]

${ }^{7}$ Huttunen, K. M.; Raunio, H.; Rautio, J. Prodrugs--from serendipity to rational design. Pharmacological Reviews 2011, 63, 750. [CrossRef] [PubMed]

${ }^{8}$ Testa, B. Prodrug research: futile or fertile? Biochemical Pharmacology 2004, 68, 2097. [CrossRef] [PubMed]

${ }^{9}$ Albert, A. Selective Toxicity - The Physicochemical Basis of Therapy, 6a ed., Chapman \& Hall: London, 1979.

${ }^{10}$ World Health Organization. Environmental Health Criteria for Formaldehyde. Volume 89. World Health Organization, Geneva, Switzerland. 1989. [Link]

11 Dow, G.; Ronald, A. L. Em Clinical Infectious Diseases: A Practical Approach; Root, R. K.; Waldvogel, F.; Corey, L.; Stamm, W. E., eds.; Oxford University Press, Inc.: New York, 1999, cap. 36.

12 Harrold, M. W.; Robin, M. Basic Concepts in Medicinal Chemistry. American Society of Health-System Pharmacists: Bethesda, 2013.
${ }^{13}$ Sneader, W. The discovery of aspirin: a reappraisal. British Medical Journal 2000, 321, 1591. [CrossRef] [PubMed]

${ }^{14}$ Madan, R. K.; Levitt, J. A review of toxicity from topical salicylic acid preparations. Journal of the American Academy of Dermatology 2014, 70, 788. [CrossRef] [PubMed]

${ }^{15}$ Rautio, J.; Kumpulainen, H.; Heimbach, T.; Oliyai, R.; Oh, D.; Jarvinen, T.; Savolainen, J.; Prodrugs: design and clinical applications. Nature Reviews Drug Discovery 2008, 7, 255. [CrossRef] [PubMed]

${ }^{16}$ Vane, J. R.; Botting, R. M. The mechanism of action of aspirin. Thrombosis Research 2003, 15, 255. [CrossRef] [PubMed]

${ }^{17}$ Lesch, J. E. The First Miracle Drugs. How the Sulfa Drugs Transformed Medicine. Oxford University Press: New York, 2007.

${ }^{18}$ Abu-Jaish, A.; Jumaa, S.; Karaman, R. Em Prodrugs Design, A New Era; Karaman, K., ed.; Nova Science Publishers: New York, 2014, cap. 2. [CrossRef]

19 Glazko, A. J.; Carnes, H. E.; Kazenko, A.; Wolf., L.M.; Reutner, T. F. Succinic acid esters of chloramphenicol. Antibiotics Annual 1957, 5, 792. [PubMed]

${ }^{20}$ Glazko, A. J.; Edgerton, W. H.; Dill, W. A.; Lenz, W. R. Chloromycetin palmitate: a synthetic ester of chloromycetin. Antibiotics and Chemotherapy 1952, 2, 234. [PubMed]

${ }^{21}$ Elayyan, S.; Karaman, D.; Mecca, G.; Scrano, L.; Bufo, S. A., Karaman, R. Antibacterial Predrugs - from 1899 till 2015. World Journal of Pharmacy and Pharmaceutical Sciences 2015, 4, 1504. [Link]

${ }^{22}$ Srinivas, N. R. The rationality for using prodrug approach in drug discovery programs for new xenobiotics: opportunities and challenges. European Journal of Drug Metabolism and Pharmacokinetics 2011, 36, 49. [CrossRef] [PubMed]

${ }^{23}$ Liu, R. Water-Insoluble Drug Formulation, 2a ed. CRC Press: Boca Raton. 2000.

${ }^{24}$ Zawilska, J. B.; Wojcieszak, J.; Olejniczak, A. B. Prodrugs: A challenge for the drug development. Pharmacological Reports 2013, 65,

1.

[PubMed] 
${ }^{25}$ Amidon, G. L. Em Techniques of Solubilization of Drugs; Yalkowsky, S. H., ed.; Marcel Dekker, Inc.: New York, 1981, p. 183211.

${ }^{26}$ Jale, M. R.; Tung, R. D.; Baker, C. T.; Spaltenstein, A. US patent 64369892002.

${ }^{27}$ Chapman, T. M.; Plosker, G. L.; Perry, C. M. Fosamprenavir: a review of its use in the management of antiretroviral therapy-naive patients with HIV infection. Drugs 2004, 64, 2101. [PubMed]

${ }^{28}$ Duggan, D. E.; Hare, L. E.; Ditzler, C. A.; Lei, B. W.; Kwan, K. C. The disposition of sulindac. Clinical Pharmacology and Therapeutics 1977, 21, 326. [PubMed]

${ }^{29}$ Mochly-Rosen, D.; Grimes, K. A Practical Guide to Drug Development in Academia: The SPARK Approach, 1a ed., Springer International Publishing: New York, 2014.

${ }^{30}$ Taylor, M. D. Improved passive oral drug delivery via prodrugs. Advanced Drug Delivery Reviews 1996, 19, 131. [CrossRef]

${ }^{31}$ Buxton, I. L. O.; Benet, L. Z. Em Goodman and Gilman's The Pharmacologic Basis of Therapeutics. Brunton, L. L., ed.; McGrawHill: New York, 2009, cap. 2.

${ }^{32}$ Sakai, J. B. Em Practical Pharmacology for the Pharmacy Technician; Sakai, J. B., ed.; Lippincott Williams \& Wilkins: Philadelphia, 2008, cap. 3.

${ }^{33}$ Lin, J. H.; Lu, A. Y. H. Role of Pharmacokinetics and Metabolism in Drug Discovery and Development. Pharmacological Reviews 1997, 49, 403. [PubMed]

${ }^{34}$ Augustijns, P.; Annaert, P.; Heylen, P; Van den Mooter, G.; Kinget, R. Drug absorption studies of prodrug esters using the Caco-2 model: evaluation of ester hydrolysis and transepithelial transport. International Journal of Pharmaceutics 1998, 166, 45. [CrossRef]

${ }^{35}$ Lipinski, C. A.; Lombardo, F.; Dominy, B. W.; Feeney, P. J. Experimental and computational approaches to estimate solubility and permeability in drug discovery and development settings. Advanced Drug
Delivery Reviews 2001, 46, 3. [CrossRef] [PubMed]

${ }^{36} \mathrm{Di}, \mathrm{L}$;; Kerns, E. H. Drug-like Properties: Concepts, Structure Design and Methods, Kerns, E. H; Di, L., ed.; Academic Press, San Diego, 2008, cap. 5.

${ }^{37}$ Davies, R. O.; Gomez, H. J., Irvin, J. D.; Walker, J. F. An overview of the clinical pharmacology of enalapril. British Journal of Clinical Pharmacology 1984, 18, $215 \mathrm{~S}$. [CrossRef] [PubMed]

${ }^{38}$ Doucette, K. E.; Aoki, F. Y. Oseltamivir: a clinical and pharmacological perspective. Expert Opinion on Pharmacotherapy 2001, 2, 1671. [CrossRef] [PubMed]

${ }^{39}$ Sugano, K.; Kansy, M.; Artursson, P.; Avdeef, A.; Bendels, S.; Di, L.; Ecker, G. F.; Faller, B.; Fischer, H.; Gerebtzoff, G.; Lennernaes, H.; Senner, F. Coexistence of passive and carrier-mediated processes in drug transport. Nature Reviews Drug Discovery 2010, 9, 597. [CrossRef] [PubMed] ${ }^{40}$ Beauchamp, L. M.; de Miranda, G. F. O.; P.; Burnette, T.; Krenitsk, T. A. Amino acid ester pro-drugs of acyclovir. Antiviral Chemistry and Chemotherapy 1992, 3, 157. [CrossRef]

${ }^{41}$ Ganapathy, M. E.; Huang, W.; Wang, H.; Ganapathy, V.; Leibach, F. H. Valacyclovir: a substrate for the intestinal and renal peptide transporters PEPT1 and PEPT2. Biochemical and Biophysical Research Communications 1998, 246, 470. [CrossRef] [PubMed]

${ }^{42}$ Yan, Z.; Sun, J.; Chang, Y.; Liu, Y.; Fu, Q; Xu, Y.; Sun, Y.; Pu, X.; Zhang, Y.; Jing, Y.; Yin, S.; Zhu, M.; He, Z. Bifunctional peptidomimetic prodrugs of didanosine for improved intestinal permeability and enhanced acidic stability: synthesis, transepithelial transport, chemical stability and pharmacokinetics. Molecular Pharmaceutics 2011, 8, 319. [CrossRef] [PubMed]

${ }^{43}$ Wang, C. L.; Fan, Y. B.; Lu, H. H.; Tsai, T. H.; Tsai, M. C.; Wang, H. P. Evidence of $d$ phenylglycine as delivering tool for improving L-dopa absorption. Journal of Biomedical Science 2010, 17, 71. [CrossRef] [PubMed]

${ }^{44}$ Brandsch, M. Drug transport via the intestinal peptide transporter PepT1. Current 
Opinion in Pharmacology 2013, 13, 881. [CrossRef] [PubMed]

${ }^{45}$ Agarwal, P.; Griffith, A.; Costantino, H.R.; Vaish, N. Gabapentin enacarbil - clinical efficacy in restless legs syndrome. Neuropsychiatric Disease and Treatment 2010, 6, 151. [CrossRef] [PubMed]

${ }^{46}$ Tsuji, A.; Tamai, I. Carrier-mediated intestinal transport of drugs. Pharmaceutical Research 1996, 13, 963. [CrossRef] [PubMed]

${ }^{47}$ Zhang, Y.; Sun, J.; Gao, Y.; Jin, L.; Xu, Y.; Lian, H.; Sun, Y.; Sun, Y.; Liu, J.; Fan, R.; Zhang, T.; He, Z. A Carrier-Mediated Prodrug Approach To Improve the Oral Absorption of Antileukemic Drug Decitabine. Molecular Pharmaceutics 2013, 10, 3195. [CrossRef] [PubMed]

${ }^{48}$ Dobson, P. D.; Kel, D. B. Carrier-mediated cellular uptake of pharmaceutical drugs: an exception or the rule? Nature Reviews Drug Discovery 2008, 7, 205. [CrossRef] [PubMed]

${ }^{49}$ Meier, C. Pro-nucleotides-recent advances in the design of efficient tools for the delivery of biologically active nucleoside monophosphates. Synlett 1998, 233. [CrossRef]

${ }^{50}$ Simplício, A. L.; Clancy, J. M.; Gilmer, J. F. Prodrugs for Amines. Molecules 2008, 13, 519. [CrossRef] [PubMed]

${ }^{51}$ ] Pradere, U.; Garnier-Amblard, E. C.; Coats, S. J.; Amblard, F.; Schinazi, R.F. Synthesis of Nucleoside Phosphate and Phosphonate Prodrugs. Chemical Reviews 2014, 114, 9154. [CrossRef] [PubMed]

${ }^{52}$ Rautio, J.; Laine, K.; Gynther, M.; Savolainen, J. Prodrug Approaches for CNS Delivery. The AAPS Journal 2008, 10, 92. [CrossRef] [PubMed]

${ }^{53}$ Bodor, N.; Buchwald, P. Recent advances in the brain targeting of neuropharmaceuticals by chemical delivery systems. Advanced Drug Delivery Reviews 1999, 36, 229. [CrossRef] [PubMed]

${ }^{54}$ Gomes, P.; Soares-da-Silva, P. L-DOPA transport properties in an immortalised cell line of rat capillary cerebral endothelial cells, RBE 4. Brain Research 1999, 829, 143. [CrossRef] [PubMed]
${ }^{55}$ Cheng, P.; Zhou, J.; Qing, Z.; Kang, W.; Liu, S.; Liu, W.; Xie, H.; Zeng, J. Synthesis of 5methyl phenanthridium derivatives: a new class of human DOPA decarboxylase inhibitors. Bioorganic \& Medicinal Chemistry Letters 2014, 24, 2712 [CrossRef] [PubMed]

${ }^{56}$ Calne, D. B.; Reid, J. L.; Vakil, S. D.; Rao, S.; Petrie, A.; Pallis, C. A.; Gawler, J. Thomas, P. K.; Hilson, A. Idiopathic Parkinsonism treated with an extracerebral decarboxylase inhibitor in combination with levodopa. British Medical Journal 1971, 3, 729 [CrossRef] [PubMed]

${ }^{57}$ Jin, S. E.; Jin, H. E.; Hong, S. S. Targeting Ltype amino acid transporter 1 for anticancer therapy: clinical impact from diagnostics to therapeutics, Expert Opinion on Therapeutic Targets 2015, 19, 1319. [CrossRef] [PubMed]

${ }^{58}$ Maeng, H. J.; Kim, E. S.; Chough, C.; Joung, M.; Lim, J. W.; Shim, C. K.; Shim, W. S. Addition of amino acid moieties to lapatinib increases the anticancer effect via amino acid transporters. Biopharmaceutics \& Drug Disposition 2014, 35, 60. [CrossRef] [PubMed] ${ }^{59}$ Shinazi, R.; Halfon, P. Marcellin, P.; Asselah, T. HCV direct-acting antiviral agents: the best interferon-free combinations. Liver International 2014, 34, 69. [CrossRef] [PubMed]

${ }^{60}$ Erion, M. D.; Reddy, K. R.; Boyer, S. H.; Matelich, M. C.; Gomez-Galeno, J. G.; Lemus, R. H.; Ugarkar, B. G.; Colby, T. J.; Schanzer, J.; van Poelje, P.D. Design, synthesis, and characterization of a series of cytochrome P450 3A-activated prodrugs (Hep-Direct prodrugs) useful for targeting phosph(on)atebased drugs to the liver. Journal of the American Chemistry Society 2004, 126, 5154. [CrossRef] [PubMed]

${ }^{61}$ Erion, M. D.; van Poelje, P.D.; MacKenna, D. A.; Colby, T. J.; Montag, A. C.; Fujitaki, J. M.; Linemeyer, D. L.; Bullough, D. A. LiverTargeted Drug Delivery Using HepDirect Prodrugs. The Journal of Pharmacology and Experimental Therapeutics 2005, 312, 554. [CrossRef] [PubMed]

${ }^{62}$ Sítio da empresa farmacêutica Ligand. Disponível em:

$<$ http://www.ligand.com/what-we- 
do/collaborations/chiva-pharmaceuticals>. Acesso em: 15 dezembro 2015.

${ }^{63}$ Elion, G. B.; Furman, P. A.; Fyfe, J. A.; de Miranda, P.; Beauchamp, L.; Schaeffer, H. J. Selectivity of action of an antiherpetic agent, 9-(2-hydroxyethoxymethyl) guanine. Proceedings of the National Academy of Sciences of the United States of America 1977, 74, 5716. [CrossRef] [PubMed]

${ }^{64}$ Szatrowski, T. P.; Nathan, C. F. Production of Large Amounts of Hydrogen Peroxide by Human Tumor Cells. Cancer Research 1991, 51, 794. [PubMed]

${ }^{65}$ a) Miller, E. W.; Albers, A. E.; Pralle, A.; Isacoff, E. Y.; Chang, C. J. Boronate-Based Fluorescent Probes for Imaging Cellular Hydrogen Peroxide. Journal of the American Chemistry Society 2005, 127, 16652; [CrossRef] [PubMed] b) Dickinson, B. C.; Chang, C. J. A. A Targetable Fluorescent Probe for Imaging Hydrogen Peroxide in the Mitochondria of Living Cell. Journal of the American Chemistry Society 2008, 130, 9638; [CrossRef] [PubMed] c) Miller, E. W.; Tulyathan, O.; Isacoff, E. Y.; Chang, C. J. Molecular imaging of hydrogen peroxide produced for cell signaling. Nature Chemical Biology 2007, 3, 263; [CrossRef] [PubMed] d) Lo, L. C.; Chu, C. Y. Development of highly selective and sensitive probes for hydrogen peroxide. Chemical Communications 2003, 2728; [CrossRef] [PubMed] e) Srikun, D.; Miller, E. W.; Domaille, D. W.; Chang, C. J. An ICT-Based Approach to Ratiometric Fluorescence Imaging of Hydrogen Peroxide Produced in Living Cells. Journal of the American Chemistry Society 2008, 130, 4596. [CrossRef] [PubMed]

${ }^{66}$ Kuang, Y.; Balakrishnan, K.; Gandhi, V.; Peng, $X$. Hydrogen Peroxide Inducible DNA Cross-Linking Agents: Targeted Anticancer Prodrugs. Journal of the American Chemistry Society 2011, 133, 19278. [CrossRef] [PubMed]

${ }^{67}$ Connors, T. A.; Whisson, M. E. Cure of mice bearing advanced plasma cell tumours with aniline mustard: the relationship between glucuronidase activity and tumour sensitivity. Nature 1966, 210, 866. [CrossRef] [PubMed]
${ }^{68}$ Trouet, A.; Passioukov, A.; Van derpoorten, K.; Fernandez, A. M.; Abarca-Quinones, J.; Baurain, R.; Lobl, T. J.; Oliyai, C.; Shochat, D.; Dubois, V. Extracellularly tumor-activated prodrugs for the selective chemotherapy of cancer: application to doxorubicin and preliminary in vitro and in vivo studies. Cancer Research 2001, 61, 2843. [PubMed]

${ }^{69}$ Tietze, L. F.; Schuster, H. J.; Schmuck, K.; Schuberth, I.; Alves, F. Bioorganic \& Medicinal Chemistry 2008, 16, 6312. [CrossRef] [PubMed]

${ }^{70}$ Frumovitz, M.; Gershenson, D.M. Fertilitysparing therapy for young women with endometrial cancer. Expert Review of Anticancer Therapy 2006, 6, 27. [CrossRef] [PubMed]

${ }^{71}$ Wallace, P.M.; Senter, P.D. In vitro and in vivo activities of monoclonal antibodyalkaline phosphatase conjugates in combination with phenol mustard phosphate. Bioconjugate Chemistry, 1991, 2, 349. [CrossRef] [PubMed]

${ }^{72}$ Springer, C. J.; Dowell, R.; Burke, P. J.; Hadley, E.; Davis, D. H.; Blakey, D. C.; Melton, R. G.; Niculescu-Duvaz, I. Optimization of alkylating agent prodrugs derived from phenol and aniline mustards: a new clinical candidate prodrug (ZD2767) for antibodydirected enzyme prodrug therapy (ADEPT). Journal of Medicinal Chemistry 1995, 38, 5051. [CrossRef] [PubMed]

${ }^{73}$ Schmidt, F.; Florent, J. C.; Monneret, C.; Straub, R.; Czech, J.; Gerken, M.; Bosslet, K. Glucuronide prodrugs of hydroxy compounds for antibody directed enzyme prodrug therapy (ADEPT): A phenol nitrogen mustard carbamate. Bioorganic \& Medicinal Chemistry Letters 1997, 7, 1071. [CrossRef]

${ }^{74}$ Schellens, J. H. M. Capecitabine. The Oncologist 2007, 12, 152. [CrossRef] [PubMed]

${ }^{75}$ Miwa, M.; Ura, M.; Nishida, M.; Sawada, N.; Ishikawa, T.; Mori, K.; Shimma, N.; Umeda, I.; Ishitsuka, H. Design of a novel oral fluoropyrimidine carbamate, capecitabine, which generates 5 -fluorouracil selectively in tumours by enzymes concentrated in human 
liver and cancer tissue. European Journal of Cancer 1998, 34, 1274. [CrossRef] [PubMed]

${ }^{76}$ Schüller, J.; Cassidy, J.; Dumont, E.; Roos, B.; Durston, S.; Banken, L.; Utoh, M.; Mori, K.; Weidekamm, E.; Reigner, B. Preferential activation of capecitabine in tumor following oral administration to colorectal cancer patients. Cancer Chemotherapy and Pharmacology 2000, 45, 291. [CrossRef] [PubMed]

${ }^{77}$ Kruspe, S.; Hahn, U. An Aptamer Intrinsically Comprising 5-Fluoro-2'deoxyuridine for Targeted Chemotherapy. Angewandte Chemie International Edition 2014, 53, 10541. [CrossRef] [PubMed]

${ }^{78}$ Svensson, L.; Tunek, A. The design and bioactivation of presystemically stable prodrugs. Drug Metabolism Reviews 1988, 19, 165. [CrossRef] [PubMed]

79 Ettmayer, P.; Amidon, G. L.; Clement, B.; Testa, B. Lessons learned from marketed and investigational prodrugs. Journal of Medicinal Chemistry 2004, 47, 2393. [CrossRef] [PubMed]

${ }^{80}$ Holstein-Rathlou, N.-H.; Laursen, L. C.; Madsen, F.; Svendsen, U. G.; Gnosspelius, Y.; Weeke, B. Bambuterol: Dose Response Study of a New Terbutaline Prodrug in Asthma. European Journal of Clinical Pharmacology 1986, 30, 7. [CrossRef] [PubMed]

${ }^{81}$ Tunek, A.; Levin, E.; Svensson, L.A. Hydrolysis of $3 \mathrm{H}$-bambuterol, a carbamate prodrug of terbutaline, in blood from humans and laboratory animals in vitro. Biochemical Pharmacology 1988, 37, 3867. [PubMed]

${ }^{82}$ Sofia, M. J.; Bao, D.; Chang, W.; Du, J.; Nagarathnam, D.; Rachakonda, S.; Reddy, P. G.; Ross, B. S.; Wang, P.; Zhang, H. R.; Bansal, S.; Espiritu, C.; Keilman, M.; Lam, A. M.; Steuer, H. M.; Niu, C.; Otto, M. J.; Furman, P. A. Discovery of a $\beta-d-2$ '-deoxy-2'- $\alpha$-fluoro-2'$\beta$-C-methyluridine nucleotide prodrug (PSI7977) for the treatment of hepatitis $C$ virus. Journal of Medicinal Chemistry 2010, 53, 7202. [CrossRef] [PubMed]

${ }^{83}$ Sofia, M. J. Beyond sofosbuvir: what opportunity exists for a better nucleoside/nucleotide to treat hepatitis C? Antiviral Research 2014, 107, 119. [CrossRef] [PubMed]

${ }^{84}$ Babusis, D.; Curry, M. P.; Denning, J.; Park, Y.; Murakami, E.; Afdhal, N.; Symonds, W.; McHutchinson, J.G.; Ray, A. Nucleotide analog levels in liver explants form HCV infected subjects undergoing liver transplantation after up to 24 weeks sofosbuvir (GS-7977) with ribavirin treatment. Hepatology 2013, 58, 737A. [link]

${ }^{85}$ Sítio da Infohep. Hepatitis C treatment factsheet: Sofosbuvir (Sovaldi). Disponível em: <http://www.infohep.org/Hepatitis-Ctreatment-factsheet-Sofosbuvir-

iSovaldii/page/2845322/>. Acesso em: 29 dezembro 2015.

${ }^{86}$ Sítio da Organização Mundial da Saúde. Disponível em: <http://www.who.int/mediacentre/factsheet s/fs164/en/>. Acesso em: 29 dezembro 2015.

87 Jessen, H. J.; Schulz, T.; Balzarini, J.; Meier, C. Bioreversible protection of nucleoside diphosphates. Angewandte Chemie International Edition 2008, 47, 8719. [CrossRef] [PubMed]

${ }^{88}$ Meier, C.; Jessen, H. J.; Schulz, T.; Weinschenk, L.; Pertenbreiter, F.; Balzarini, J. Rational Development of Nucleoside Diphosphate Prodrugs: DiPPro-Compounds. Current Medicinal Chemistry 2015, 22, 3933. [CrossRef] [PubMed]

89 a) Gollnest, T.; Dinis de Oliveira, T.; Schols, D.; Balzarini, J.; Meier, C. Lipophilic prodrugs of nucleoside triphosphates as biochemical probes and potential antivirals. Nature Communications. 2015, 6, 8716; [CrossRef] [PubMed] b) Gollnest, T.; Dinis de Oliveira, T.; Rath, A.; Hauber, I.; Schols, D.; Balzarini, J.; Meier, C. Membrane-permeable Triphosphate Prodrugs of Nucleoside Analogues. Angewandte Chemie International Edition 2016, 55, 5255-5258. [CrossRef] [PubMed]

${ }^{90}$ Pertenbreiter, F.; Balzarini, J.; Meier, C. Nucleoside Mono- and Diphosphate Prodrugs of 2',3'-Dideoxyuridine and 2',3'-Dideoxy- 
Souza, M. C. B. A.; Huchting, J.

2', 3'-didehydrouridine. ChemMedChem 2015, 10, 94. [CrossRef] [PubMed]

${ }^{91}$ Schaadt, R.; Sweeney, D.; Shinabarger, D.; Zurenko, G. Antimicrobial Agents and Chemotherapy 2009, 53, 3236. [CrossRef] [PubMed]

${ }^{92}$ Braun, V.; Pramanik, A.; Gwinner, T.; Koeberle, M.; Bohn, E. Sideromycins: tools and antibiotics. Biometals 2009, 22, 3. [CrossRef] [PubMed]
${ }^{93} \mathrm{Ji}, \mathrm{C}$.; Miller, M. J. Chemical syntheses and in vitro antibacterial activity of two desferrioxamine B-ciprofloxacin conjugates with potential esterase and phosphatase triggered drug release linkers. Bioorganic and Medicinal Chemistry 2012, 20, 3828. [CrossRef] [PubMed]

${ }^{94}$ Möllmann, U.; Heinisch, L.; Bauernfeind, A.; Köhler, T.; Ankel-Fuchs, D. Siderophores as drug delivery agents: application of the "Trojan Horse" strategy. Biometals 2009, 22, 615. [CrossRef] [PubMed] 